\title{
Regioselective domino metathesis of 2-substituted 7-oxanorborn-5-enes
}

\author{
Odón Arjona*, Aurelio G. Csákÿ, M. Carmen Murcia, and Joaquín Plumet* \\ Departamento de Química Orgánica I. Facultad de Química. Universidad Complutense. 28040 \\ Madrid. Spain \\ E-mail: plumety@quim.ucm.es
}

Dedicated to Prof. Marcial Moreno on occasion of his $60^{\text {th }}$ birthday

(received 10 Jan 02; accepted 16 Apr 02; published on the web 24 Apr 02)

\begin{abstract}
The regiochemistry of the domino metathesis reaction of 2-endo substituted 7-oxanorbornenic allyl amines and allyl ethers have been studied. The results lead to two alternative reaction pathways, starting either by ring-opening metathesis of the endocyclic $\mathrm{C}=\mathrm{C}$ bond or by carbometallation of the $\mathrm{C}=\mathrm{C}$ bond of the alkenyl chain.
\end{abstract}

Keywords: Regioselective, metathesis, 7-oxanorborn-5-ene, carbometallation

\section{Introduction}

The 7-oxabicyclo[2.2.1]hept-5-ene derivatives (7-oxanorborn-5-enes) are important chiral templates because these compounds show a broad spectra of reactivity, generally in a predictable regio- and stereocontrolled fashion. ${ }^{1}$ We have recently been interested in transformations which involve the endocyclic $\mathrm{C}=\mathrm{C}$ bond, due to the possibility of generating two stereocentres in a single operation using these types of reactions. ${ }^{2,3,4}$ In these cases, when the starting material is not symmetrically substituted with respect to the $\mathrm{C}=\mathrm{C}$ moiety, as in the 2-substituted derivatives 1, regiochemical issues arise, which must be understood prior to the development of new synthetic planning starting from these materials (Scheme 1).
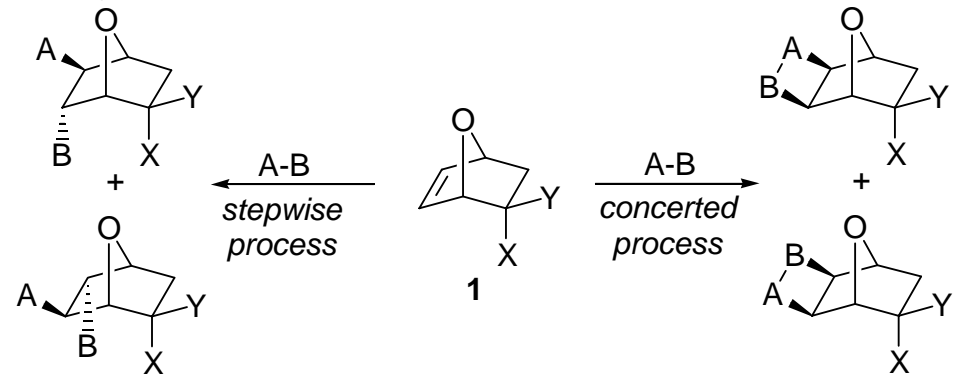

Scheme 1 
We have focused our attention on olefin metathesis processes, which have emerged as powerful tools in organic synthesis. ${ }^{5}$ In particular, ring-closing metathesis (RCM) has been extensively used for the preparation of cyclic compounds from acyclic precursors. In this context, we are particularly interested in the domino metathesis reaction (combination of ring opening -ROM-, cross -CM- and ring closing -RCM- metatheses) ${ }^{4}$ as a means of synthesizing bicyclic tetrahydrofuran derivatives from 7-oxanorbornenes in a highly stereoselective fashion (Scheme 2). ${ }^{6}$
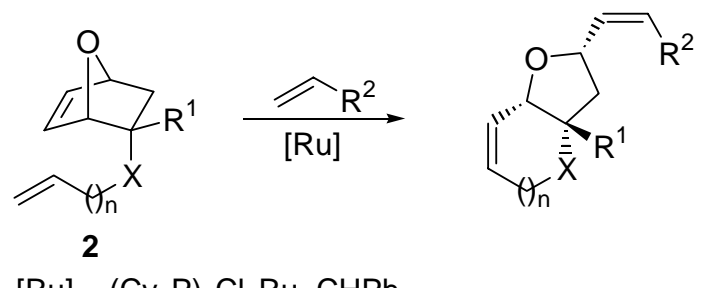

$[\mathrm{Ru}]=\left(\mathrm{Cy}_{3} \mathrm{P}\right)_{2} \mathrm{Cl}_{2} \mathrm{Ru}=\mathrm{CHPh}$

\section{Scheme 2}

\section{Results}

Nucleophilic addition to the carbonyl group of 7-oxanorborn-5-ene-2-one (1a) takes place with complete exo diastereoselectivity ${ }^{7}$ giving rise to the endo alcohols $\mathbf{1 b}$-d (Scheme 3). Etherification with allyl bromide affords the corresponding endo-7-oxanorborn-5-enylallyl ethers 2. Treatment of compounds $\mathbf{2}$ with allyl acetate in the presence of Grubb's ruthenium catalyst $\left(\mathrm{Cl}_{2}(\mathrm{PCy})_{2} \mathrm{Ru}=\mathrm{CHPh},[\mathrm{Ru})\right.$ (Scheme 3$)$ afforded variable amounts of the corresponding crossmetathesis 3, 4 and domino metathesis products 5, 6. ${ }^{4}$ The reaction could be optimized for selectively obtaining the cis-fused 2,6-dioxabicyclo[3.4.0]nonenes ${ }^{8} \mathbf{5}$ and $\mathbf{6}$ with high regioselectivity in favour of isomers $5 .^{9}$ The results are tabulated in Table 1.

Table 1. Domino metathesis of allyl ethers $\mathbf{2}^{\mathrm{a}}$

\begin{tabular}{lllllllll}
\hline No. & $\mathbf{2}$ & $\mathrm{R}^{1}$ & {$[\mathrm{Ru}]^{\mathrm{b}}$} & $\mathrm{T}\left({ }^{\mathrm{o}} \mathrm{C}\right)$ & $\mathrm{t}(\mathrm{h})$ & $\mathbf{3 , 4}(\%)^{\mathrm{c}}$ & $\mathbf{5}(\%)^{\mathrm{c}}$ & $\mathbf{6 , 7}(\%)^{\mathrm{c}}$ \\
\hline 1 & $\mathbf{2 a}$ & $\mathrm{H}$ & 0.06 & 25 & 12 & $\mathbf{3 a}, \mathbf{4 a}(10)^{\mathrm{d}}$ & $\mathbf{5 a}(40)$ & $\mathbf{7}(05)$ \\
2 & $\mathbf{2 a}$ & $\mathrm{H}$ & 0.06 & 40 & 5 & $\mathbf{3 a}, \mathbf{4 a}(5)^{\mathrm{d}}$ & $\mathbf{5 a}(50)$ & $\mathbf{7}(07)$ \\
2 & $\mathbf{2 a}$ & $\mathrm{H}$ & 0.08 & 40 & 0.5 & -- & $\mathbf{5 a}(80)$ & $\mathbf{7}(10)$ \\
2 & $\mathbf{2 b}$ & $\mathrm{Ph}$ & 0.08 & 40 & 0.5 & --- & $\mathbf{5 b}(80)$ & $\mathbf{6 b}(8)$ \\
3 & $\mathbf{2 c}$ & $\mathrm{Et}$ & 0.08 & 40 & 0.5 & --- & $\mathbf{5 c}(70)$ & $\mathbf{6 c}(12)$ \\
\hline
\end{tabular}

a All reactions were carried out in $\mathrm{CH}_{2} \mathrm{Cl}_{2}(0.034 \mathrm{M}) .{ }^{\mathrm{b}}$ Mole of Grubbs' catalyst per mole of 2. ${ }^{\mathrm{c}}$ Isolated yields. (d) $\mathbf{3 a : 4 a}=80: 20$. 


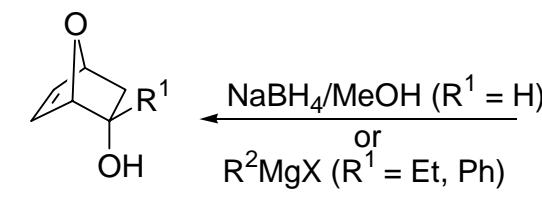

1b-d

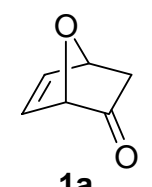

$1 a$

i) $\mathrm{NaH}, \mathrm{DMF}$

ii) $\mathrm{CH}_{2}=\mathrm{CHCH}_{2} \mathrm{Br}$

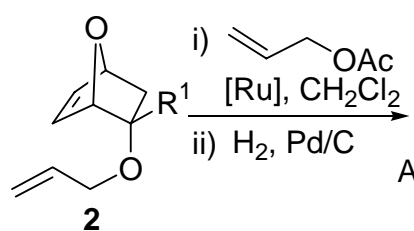

2

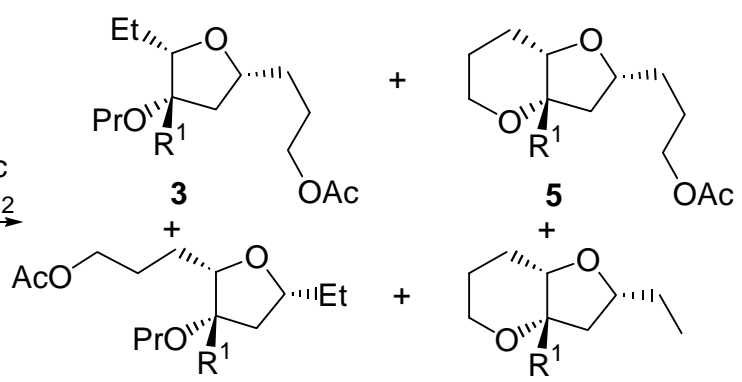

4

6

$$
\begin{aligned}
& \text { 2a-6a, } 7, R^{1}=H \\
& 2 b-6 b, R^{2}=P h \\
& 2 c-6 c, R^{2}=E t
\end{aligned}
$$

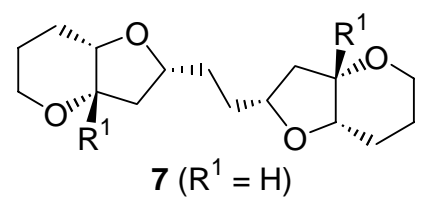

\section{Scheme 3}

In a similar fashion, nucleophilic addition to the $\mathrm{C}=\mathrm{N}$ linkage of imine $\mathbf{8}$ occurs with full diastereoselectivity on the exo face of the bicyclic system, giving rise to the endo-amines 9a,b (Scheme 4). ${ }^{10}$ Also, the Strecker cyanide addition afforded the $\alpha$-aminonitrile $9 \mathrm{c}$ as a single diastereomer. ${ }^{11}$ Protection of the amino group of amines 9 with benzyl bromide or di-tert-butyl dicarbonate gave compounds $\mathbf{1 0}$.

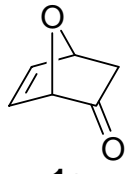

$1 a$

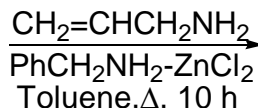

Toluene, $\Delta, 10 \mathrm{~h}$

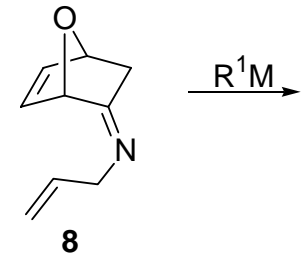

9a, $R^{1} M=\mathrm{LiAlH}_{4}\left(R^{1}=H\right)$,

9b, $\mathrm{PhMgBr}\left(\mathrm{R}^{1}=\mathrm{Ph}\right)$,

9c, TMS-CN, $\mathrm{ZnCl}_{2}\left(\mathrm{R}^{1}=\mathrm{CN}\right)$<smiles>[R]N1CCC[C@H]2O[C@@H](CCCOC(C)=O)C[C@]21[R1]</smiles>

11

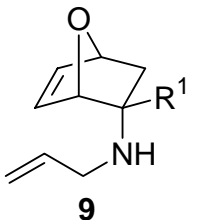

$\mathrm{BnBr}$ or $\mathrm{Boc}_{2} \mathrm{O}$<smiles>[R]C1C2C=CC(O2)C1([R])N([R])CC=C</smiles>

10

\section{Scheme 4}


The results of the domino metathesis of compounds $\mathbf{9}$ and $\mathbf{1 0}$ are presented in Table 2. It is worth mentioning that when the endo-7-oxanorborn-5-enylallyl amides 10a-c were treated with $6 \%[\mathrm{Ru}]$ at $25^{\circ} \mathrm{C}$ in the presence of allyl acetate, the reaction was highly regioselective, and compounds $\mathbf{1 1}$ were the only isomers that could be detected in the reaction mixture (Scheme 4). ${ }^{12}$ Under similar reaction conditions (Table 1, entry 1), the allyl ethers $\mathbf{2}$ afforded a mixture of regioisomers of the cross metathesis and domino metathesis products in low overall yields.

Table 2. Domino metathesis of amines 9 and $\mathbf{1 0}^{\mathrm{a}}$

\begin{tabular}{ccccc}
\hline No. & $\mathbf{9 , 1 0}$ & $\mathrm{R}^{1}$ & $\mathrm{R}^{2}$ & $\mathbf{1 1}(\%)^{\mathrm{b}}$ \\
\hline 1 & $\mathbf{9 a}$ & $\mathrm{H}$ & $\mathrm{H}$ & --- \\
2 & $\mathbf{1 0 a}$ & $\mathrm{H}$ & Boc & $\mathbf{1 1 a}(65)$ \\
3 & $\mathbf{1 0 b}$ & $\mathrm{Ph}$ & Boc & $\mathbf{1 1 b}(60)$ \\
4 & $\mathbf{1 0 c}$ & $\mathrm{CN}$ & Boc & $\mathbf{1 1 c}(60)$ \\
5 & $\mathbf{1 0 d}$ & $\mathrm{H}$ & $\mathrm{Bn}$ & --- \\
\hline
\end{tabular}

(a) All reactions were carried out in $\mathrm{CH}_{2} \mathrm{Cl}_{2}(0.034 \mathrm{M})$ with 0.06 mole of [Ru] per mole of 9 or 10. (b) Isolated yields.

Treatment of compound 9a with [Ru] $(6 \% \mathrm{~mol})$ in the presence of allyl acetate led only to the recovery of the starting materials (entry 1). We presumed that this result could stem from deactivation of the catalyst by the $\mathrm{NH}$ group. ${ }^{13}$ On the other hand, protection of the amine as Boc-derivative rendered compounds 10a-c, where the lone pairs on nitrogen are less accessible due to delocalization with the carbamate moiety as well as steric encumbrance. Compound 10a was an active substrate for the metathesis process (entry 2). This result was extended to compounds $\mathbf{1 0 b}, \mathbf{c}$ (entries 3-4). It was also noted that the N-benzyl derivative 10d (entry 5) was not an active substrate for the domino metathesis process under these reaction conditions, giving rise to the recovery of the starting material.

\section{Discussion}

The domino metathesis reaction of the Boc-protected allyl amines 10a-c took place directly to afford the corresponding oxazabicycles $\mathbf{1 1}$ as single regioisomers. On the other hand, under the same reaction conditions, the metathesis of the allyl ethers $\mathbf{2}$ gave rise to a mixture of products of cross and domino metathesis with low overall yields. An increase in catalyst loading and reaction temperature finally rendered good yields of the domino metathesis products $\mathbf{5}$ and $\mathbf{6}$. These were obtained as a mixture of both regioisomers.

On the basis of these observations, the regiochemical outcome of the domino metathesis reactions of 2-substituted 7-oxanorborn-5-enes $\mathbf{2}$ and $\mathbf{1 0}$ could be understood at first by a sequence of ROM-CM-RCM reactions (Scheme 5). Thus, the initial ROM of the endocyclic 
$\mathrm{C}=\mathrm{C}$ bond would lead to the formation of two regioisomeric carbenes $\mathbf{I}-\mathbf{A}$ and $\mathbf{I}-\mathbf{B}$. Intermolecular $\mathrm{CM}$ with allyl acetate would give rise to the ROM-CM intermediates $\mathbf{3}, \mathbf{4}(\mathrm{X}=\mathrm{O})$ or 12, 13 ( $\mathrm{X}=\mathrm{NBoc})$. These may be converted to the final products by RCM.

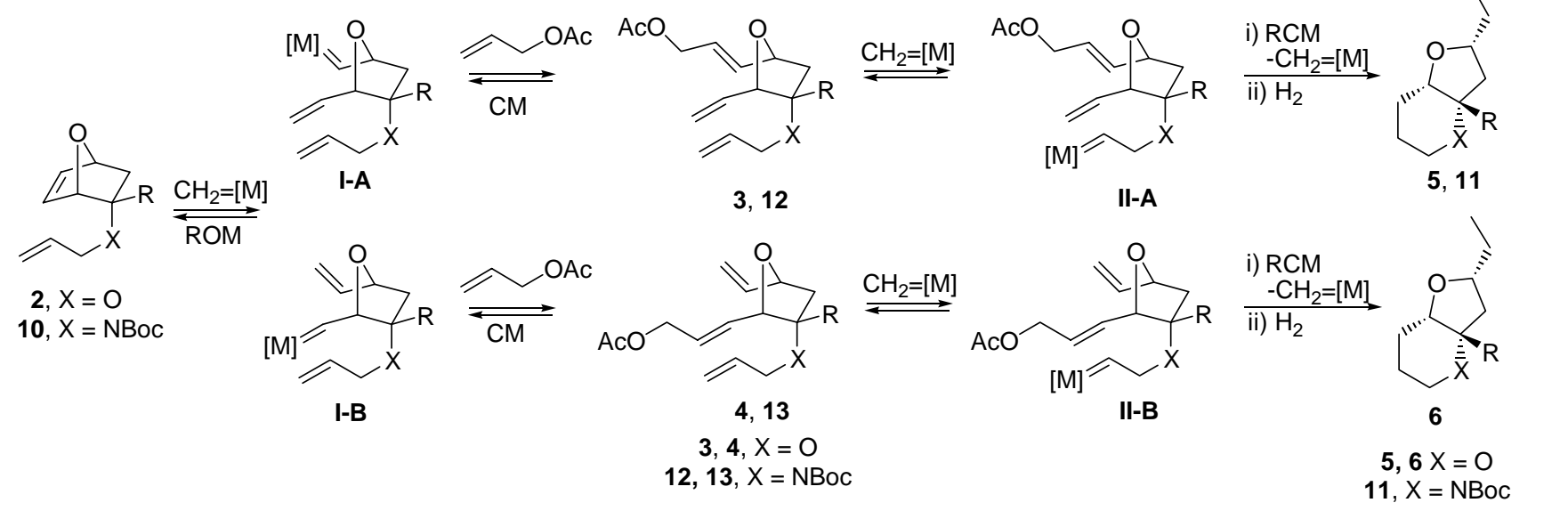

\section{Scheme 5}

The predominant formation of compounds $\mathbf{5}(\mathrm{X}=\mathrm{O})$ starting from the compounds $\mathbf{2}$ could be accounted for by steric interactions between the endo allyl chain at C-2 of the starting bicycle and the ligands of the metal in the first carbometallation step leading to intermediate $\mathbf{I}-\mathbf{B}$ and also by steric inhibition of the reactivity of carbene $\mathbf{I}-\mathbf{B} .{ }^{3 \mathrm{c}}$ The exclusive formation of compounds $\mathbf{1 1}$ ( $\mathrm{X}=\mathrm{NBoc}$ ) in the case of amines $\mathbf{1 0}$ may be explained in terms of the steric encumbrance of the Boc group, which would render the endo substituent more sterically demanding than in the previous case. This reaction pathway is supported by the isolation of intermediates $\mathbf{3}$ and $\mathbf{4}$ ( $\mathrm{X}=$ $\mathrm{O})$. However, formation of the corresponding regioisomeric intermediates $\mathbf{1 2}$ and $\mathbf{1 3}$ in the case of amines $\mathbf{1 0}$ was not observed.

Therefore, an alternative reaction pathway might be proposed (Scheme 6): initial carbometallation of the $\mathrm{C}=\mathrm{C}$ bond of the allyl chain in $\mathbf{1 0}$ may lead to carbene III, which may be stabilized by chelation with the carbamate moiety. RCM followed by CM with allyl acetate would render exclusively compounds $\mathbf{1 1 .}$

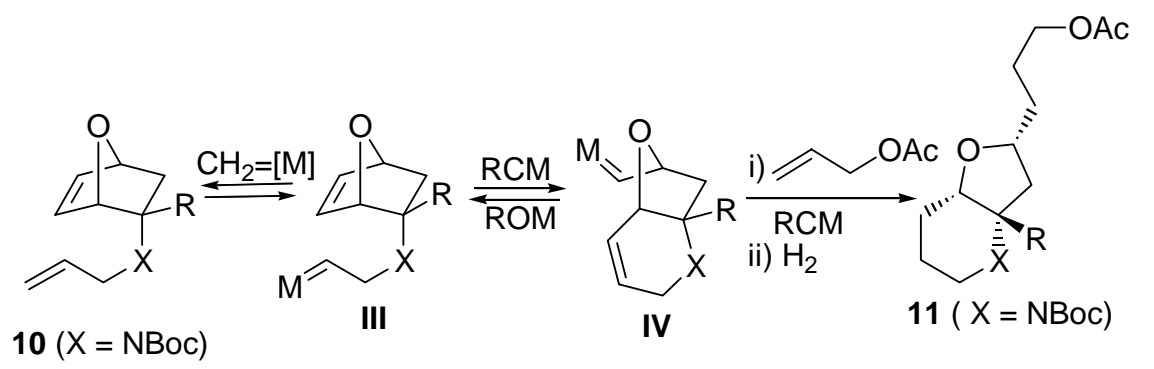

\section{Scheme 6}


In order to establish the main reaction pathway, we have performed the metathesis reaction starting from propylamine $\mathbf{1 4}$ (Scheme 7). The propyl chain in $\mathbf{1 4}$ should have the same steric requirements than the allyl chain in $\mathbf{1 1}$. Therefore, in the absence of the allyl double bond, the reaction is forced to follow the ROM-CM-RCM pathway. We have observed that the corresponding metathesis products 15 and 16 were obtained in a 60 : 40 ratio. These results parallel those obtained with the allyl ethers $\mathbf{2}$, and are different from those obtained starting from the allyl amines $\mathbf{1 0 .}$

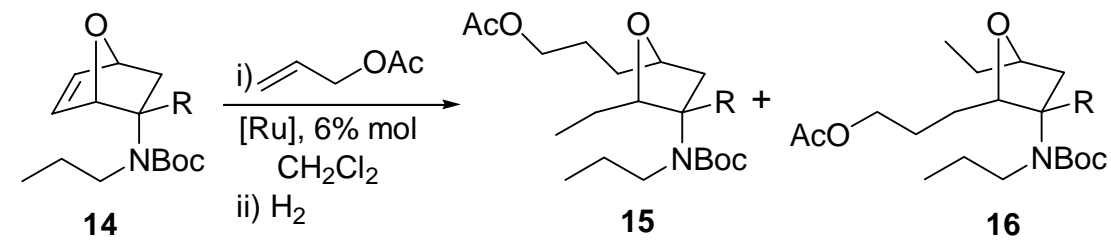

\section{Scheme 7}

\section{Conclusions}

The intramolecular domino metathesis reaction of 2-endo substituted 7-oxanorbornenes constitutes a useful process for the assembly of fused tetrahydrofuran rings with defined stereochemistry. This procedure is suitable for the introduction of a quaternary stereogenic center at the bridgehead position C-5 of the resulting new bicyclic analogs. In order to obtain high levels of regioselectivity, the nature of the lateral unsaturated chain is of crucial importance. Thus, regioselectivity is maximal when the domino metathesis reaction is directed first to the double bond of the lateral chain. This may be steered in the presence of groups able to stabilize the intermediate carbene by chelation. ${ }^{14}$ Instead, the ROM-CM-RCM sequence starting from the $\mathrm{C}=\mathrm{C}$ endocyclic bond affords the domino metathesis products with diminished regioselectivity.

\section{Experimental Section}

General Procedures. Silica gel $60 \mathrm{~F}_{254}$ was used for TLC, and the spots were detected with UV and vanillin solution. Flash column chromatography was carried out on silica gel 60. IR spectra have been recorded as $\mathrm{CHCl}_{3}$ solutions. ${ }^{1} \mathrm{H}$ and ${ }^{13} \mathrm{C} \mathrm{NMR}$ spectra were recorded at 200 or 300 $\mathrm{MHz}$ and 50.5 or $75.5 \mathrm{MHz}$. MS was carried out at $70 \mathrm{eV}$.

\section{General procedure for metathesis of allylic ethers 2 a-c}

To a solution of $\mathbf{2 a - c}(0.50 \mathrm{mmol})$ and allylic acetate $(0.50 \mathrm{mmol})$ in anhydrous $\mathrm{CH}_{2} \mathrm{Cl}_{2}(13 \mathrm{~mL})$ at rt, was added $\left(\mathrm{Cy}_{3} \mathrm{P}\right)_{2} \mathrm{Cl}_{2} \mathrm{Ru}=\mathrm{CHPh}(33 \mathrm{mg}, 0.04 \mathrm{mmol})$ dissolved in $\mathrm{CH}_{2} \mathrm{Cl}_{2}(2 \mathrm{~mL})$. The reaction mixture was warmed to reflux, for 1-4 h, until the starting material disappeared (TLC 
monitoring). After conversion was complete, the solvent was removed under reduced pressure. The reaction mixture was filtered through a pad of silica gel, which was washed with a mixture of hexane : ethyl acetate $=3: 2$. After removal of the solvent under reduced pressure, the crude reaction product was dissolved in $\mathrm{MeOH}(5.5 \mathrm{~mL}), 10 \% \mathrm{Pd}$ on charcoal $(10 \%)$ was added and the mixture was hydrogenated at 50 Psi for $5 \mathrm{~h}$. Fitration of the catalyst and evaporation of the solvent, afforded a brown oil which was purified by chromatography (silica gel, hexane : ethyl acetate $=3: 2$ ).

$\left(1 S^{*}, 3 R^{*}, 5 S^{*}\right)$ - 3-Acetoxypropyl-2,6-dioxa[4.3.0]nonane (5a). Colorless oil. IR $\left(\mathrm{CHCl}_{3}\right) v$ 1730, $1215 \mathrm{~cm}^{-1} .{ }^{1} \mathrm{H}$ RMN (300 MHz, $\left.\mathrm{CDCl}_{3}\right) \delta 1.30(\mathrm{~m}, 1 \mathrm{H}), 1.50-1.90(\mathrm{~m}, 8 \mathrm{H}), 2.05(\mathrm{~s}, 3 \mathrm{H})$, 2.20 (m, 1H), 3.25-3.40 (m, 2H), $3.55(\mathrm{~m}, 1 \mathrm{H}), 3.95(\mathrm{~m}, 2 \mathrm{H}), 4.05(\mathrm{t}, 2 \mathrm{H}, \mathrm{J}=6.3 \mathrm{~Hz}) \mathrm{ppm} .{ }^{13} \mathrm{C}$ RMN (50.5 MHz, $\left.\mathrm{CDCl}_{3}\right) \delta 171.2,77.5,76.4,76.1,66.6,64.5,39.3,32.8,30.9,25.3,25.2,20.5$ ppm. Anal. Caldc. for $\mathrm{C}_{12} \mathrm{H}_{20} \mathrm{O}_{4}$ : C, 63.14; H, 8.83. Found: C, 63.35; H, 8.94.

$\left(1 S^{*}, 3 R^{*}\right.$, 5S*)- 3-Ethyl-bis(2,6-dioxa[4.3.0]nonane (7). Colorless oil. IR $\left(\mathrm{CHCl}_{3}\right) \vee 1225 \mathrm{~cm}^{-1} .{ }^{1} \mathrm{H}$ RMN (300MHz, $\left.\mathrm{CDCl}_{3}\right) \delta 1.30(\mathrm{~m}, 2 \mathrm{H}), 1.50-1.95(\mathrm{~m}, 12 \mathrm{H}), 2.20$ (m, 2H), 3.40 (t, 4H, J = $\left.6.3 \mathrm{~Hz}\right), 3.55(\mathrm{~m}, 2 \mathrm{H})$, 3.95 (m, 4H) ppm. ${ }^{13} \mathrm{C}$ RMN $\left(50.5 \mathrm{MHz}, \mathrm{CDCl}_{3}\right) \delta 78.6,78.2,77.2$, 76.4, 66.9, 39.8, 39.6, 33.6, 33.3, 25.7, 25.6, 20.9 ppm. Anal. Caldc. for $\mathrm{C}_{16} \mathrm{H}_{26} \mathrm{O}_{4}$ : C, 68.08; H, 9.28. Found: C, 68.25; H, 9.54.

$\left(1 S^{*}, 3 R^{*}, 5 R^{*}\right)-3$-Acetoxypropyl-5-phenyl-2,6-dioxa [4.3.0]nonane, (5b). Colorless oil. IR $\left(\mathrm{CHCl}_{3}\right) \vee 1730,1650,1215 \mathrm{~cm}^{-1} .{ }^{1} \mathrm{H}$ RMN (300 MHz, $\left.\mathrm{CDCl}_{3}\right) \delta 1.60-1.80(\mathrm{~m}, 9 \mathrm{H}), 2.05(\mathrm{~s}$, 3H), 2.20 (dd, 1H, J = 12.8, 7.2 Hz), 3.30 (td, $1 \mathrm{H}, \mathrm{J}=12.2,1.3 \mathrm{~Hz}$ ), 3.65 (bd, $1 \mathrm{H}, \mathrm{J}=12.2 \mathrm{~Hz}$ ), 4.05 (m, 3H, H-3), 4.40 (m, 1H), 7.22-7.40 (m, 5H) ppm. ${ }^{13} \mathrm{C}$ RMN (50.5 MHz, $\left.\mathrm{CDCl}_{3}\right) \delta 172.3$, 141.1, 128.6, 127.1, 126.1, 82.5, 76.9, 65.8, 64.6, 63.1, 49.9, 32.9, 25.3, 23.6, 21.1, 20.0 ppm. Anal. Cald. for $\mathrm{C}_{18} \mathrm{H}_{24} \mathrm{O}_{4}$ : C, 71.03; H, 7.95. Found: C, 71.12; $\mathrm{H}, 8.04$.

$\left(1 S^{*}, 3 R^{*}, 5 R^{*}\right)$-3-Ethyl-5-phenyl-2,6-dioxa[4.3.0]nonane (6b). Colorless oil. IR $\left(\mathrm{CHCl}_{3}\right) v$ 1650, $1215 \mathrm{~cm}^{-1} .{ }^{1} \mathrm{H}$ RMN (300 MHz, $\left.\mathrm{CDCl}_{3}\right) \delta 0.95$ (t, 3H, J = 7.2 Hz), 1.80-2.05 (m, 8H), 3.30 (td, $1 \mathrm{H}, \mathrm{J}=12.2,1.3 \mathrm{~Hz}), 3.65(\mathrm{~m}, 1 \mathrm{H}), 4.02(\mathrm{~m}, 1 \mathrm{H}), 4.40(\mathrm{~m}, 1 \mathrm{H}), 7.22-7.40(\mathrm{~m}, 5 \mathrm{H}) \mathrm{ppm} .{ }^{13} \mathrm{C}$ RMN (50.5 MHz, $\left.\mathrm{CDCl}_{3}\right) \delta 139.1,128.2,127.7,125.8,79.4,75.9,69.5,62.6,46.8,29.3,26.6$, 23.1, 20.9, 7.2 ppm. Anal. Calcd. for $\mathrm{C}_{15} \mathrm{H}_{20} \mathrm{O}_{2}$ : C, 77.55; H, 8.68. Found: C, 77.62; H, 8.73.

$\left(1 S^{*}, 3 R^{*}, 5 S^{*}\right)-3$-Acetoxypropyl-5-ethyl-2,6-dioxa[4.3.0]nonane (5c). Colorless oil. IR $\left(\mathrm{CHCl}_{3}\right) \vee 1730,1215 \mathrm{~cm}^{-1} .{ }^{1} \mathrm{H}$ RMN $\left(300 \mathrm{MHz}, \mathrm{CDCl}_{3}\right) \delta 0.95(\mathrm{t}, 3 \mathrm{H}, \mathrm{J}=7.0 \mathrm{~Hz}), 1.60-1.95$ (m, 12H), 2.05 (s, 3H), 3.50 (m, 2H), $3.65(\mathrm{~m}, 1 \mathrm{H}), 3.95(\mathrm{~m}, 1 \mathrm{H}), 4.05(\mathrm{t}, 2 \mathrm{H}, \mathrm{J}=6.3 \mathrm{~Hz}) \mathrm{ppm}$. ${ }^{13} \mathrm{C}$ RMN (50.5 MHz, $\left.\mathrm{CDCl}_{3}\right) \delta 171.7,80.7,78.4,75.1,64.6,62.5,42.3,31.8,26.3,25.9,25.1$, 21.4, 20.5 ppm. Anal. Calcd. for $\mathrm{C}_{14} \mathrm{H}_{24} \mathrm{O}_{4}$ : C, 65.60; H, 9.44. Found: C, 65.74; H, 9.57.

$\left(1 S^{*}, 3 R^{*}, 5 S^{*}\right)$-3,5-Ethyl-2,6-dioxa[4.3.0]nonane, (6c). Colorless oil. IR $\left(\mathrm{CHCl}_{3}\right) \vee 1225 \mathrm{~cm}^{-1}$. ${ }^{1} \mathrm{H}$ RMN (300 MHz, CDCl 3 ) $\delta 0.90(\mathrm{t}, 3 \mathrm{H}, \mathrm{J}=7.0 \mathrm{~Hz}), 0.95(\mathrm{t}, 3 \mathrm{H}, \mathrm{J}=7.0 \mathrm{~Hz}), 1.60-1.95(\mathrm{~m}$, $10 \mathrm{H}), 3.55$ (m, 2H), $\left.3.75(\mathrm{~m}, 1 \mathrm{H}), 3.95(\mathrm{~m}, 1 \mathrm{H}) \mathrm{ppm} .{ }^{13} \mathrm{C} \mathrm{RMN} \mathrm{(50.5} \mathrm{MHz,} \mathrm{CDCl}_{3}\right) \delta$ 79.2, 78.5, 70.1, 62.2, 38.3, 31.2, 26.4, 25.8, 23.1, 8.4, 8.1 ppm. Anal. Calcd. for $\mathrm{C}_{11} \mathrm{H}_{20} \mathrm{O}_{2}$ : C, 71.70; $\mathrm{H}$, 10.94. Found: C, 71.92; H, 10.97. 


\section{General procedure for metathesis of allylic amines 10a-c and 14}

To a solution of $\mathbf{1 0 a}-\mathbf{c}$ or $\mathbf{1 4}(0.20 \mathrm{mmol})$ and allylic acetate $(0.20 \mathrm{mmol})$ in anhydrous $\mathrm{CH}_{2} \mathrm{Cl}_{2}$ $(5 \mathrm{~mL})$ at r.t., was added $\left(\mathrm{Cy}_{3} \mathrm{P}\right)_{2} \mathrm{Cl}_{2} \mathrm{Ru}=\mathrm{CHPh}(16 \mathrm{mg}, 0.02 \mathrm{mmol})$ dissolved in $\mathrm{CH}_{2} \mathrm{Cl}_{2}$ $(1.5 \mathrm{~mL})$. The reaction mixture was stirred at room temperature for 24 hours. After conversion was complete (TLC monitoring), the solvent was removed under reduced pressure. The reaction mixture was filtered through a pad of silica gel, which was washed with a mixture of $\mathrm{CH}_{2} \mathrm{Cl}_{2} / \mathrm{AcOEt}$, 4:1. After removal of the solvent under reduced pressure, the crude reaction product was dissolved in $\mathrm{MeOH}(5.0 \mathrm{~mL}), 10 \% \mathrm{Pd}$ on charcoal $(10 \%)$ was added and the mixture was hydrogenated at 50 Psi for $5 \mathrm{~h}$. Fitration of the catalyst and evaporation of the solvent, afforded a brown oil which was purified by chromatography (silica gel, $\mathrm{CH}_{2} \mathrm{Cl}_{2} / \mathrm{AcOEt}, 4: 1$ ).

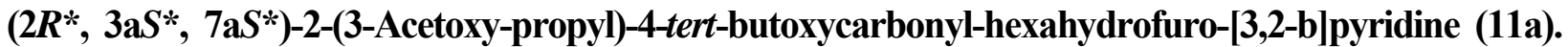
Colorless oil. IR $\left(\mathrm{CHCl}_{3}\right) \vee 1715,1220 \mathrm{~cm}^{-1} .{ }^{1} \mathrm{H} \mathrm{RMN}\left(300 \mathrm{MHz}, \mathrm{CDCl}_{3}\right) \delta 1.48$ (s, 9H), 1.55-1.80 (m, 8H), 2.05 (s, 3H), 2.10 (m, 2H), 2.90 (td, 1H, J = 9.2, $4.3 \mathrm{~Hz}$ ), 3.75-4.00 (m, 3H), 4.09 (t, 2H, J = 6.7 $\mathrm{Hz}), 4.62(\mathrm{~m}, 1 \mathrm{H}) \mathrm{ppm} .{ }^{13} \mathrm{C} \mathrm{RMN}\left(50.5 \mathrm{MHz}, \mathrm{CDCl}_{3}\right) \delta 171.6,158.7,80.3,77.6,73.6,64.8$, 56.8, 47.4, 35.5, 30.5, 29.7, 28.2, 27.4, 25.2, 20.1 ppm. Anal. Calcd. for $\mathrm{C}_{17} \mathrm{H}_{29} \mathrm{NO}_{5}$ : C, 62.36; $\mathrm{H}$, 8.93; N, 4.48. Found: C, 62.47; H, 8.90, N, 4.54.

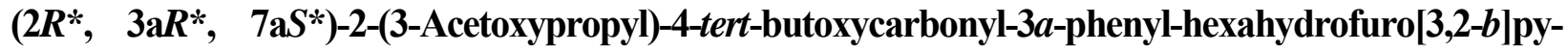
ridine (11b). Colorless oil. IR $\left(\mathrm{CHCl}_{3}\right) \vee 1710,1650,1225 \mathrm{~cm}^{-1} .{ }^{1} \mathrm{H} \mathrm{RMN}\left(300 \mathrm{MHz}, \mathrm{CDCl}_{3}\right) \delta 1.50$ (s, 9H), 1.60-1.80 (m, 8H), 2.05 (s, 3H), 2.20 (m, 2H), 3.80-4.05 (m, 4H), 4.10 (t, 2H, J = 6.7 Hz), 7.25-7.40 (m, 5H) ppm. ${ }^{13} \mathrm{C} \mathrm{RMN}\left(50.5 \mathrm{MHz}, \mathrm{CDCl}_{3}\right) \delta 172.1,158.6,141.3,128.7,127.1,126.1,80.4,77.9$, 74.1, 64.8, 59.1, 46.6, 37.5, 30.2, 29.5, 28.1, 27.7, 25.1, 20.2 ppm. Anal. Calcd. for $\mathrm{C}_{23} \mathrm{H}_{33} \mathrm{NO}_{5}$ : C, 68.46; H, 8.24; N, 3.47. Found: C, 68.49; H, 8.27, N, 3.42.

$\left(2 R^{*}, 3 \mathrm{a} R^{*}, 7 \mathrm{a} S^{*}\right)-2-(3-A c e t o x y p r o p y l)-4-t e r t-b u t o x y c a r b o n y l-3 a-c y a n o-h e x a h y d r o$ furo[3,2-b]py-ridine (11c). IR $\left(\mathrm{CHCl}_{3}\right) \vee 2250,1715,1225 \mathrm{~cm}^{-1} .{ }^{1} \mathrm{H} \mathrm{RMN}\left(300 \mathrm{MHz}, \mathrm{CDCl}_{3}\right)$ $\delta 1.50$ (s, 9H), 1.60-1.85 (m, 8H), 2.05 (s, 3H), 2.15 (m, 2H), 3.85-4.10 (m, 3H), 4.12 (t, 2H, J = 6.7 Hz), 4.25 (m, 1H) ppm. $\left.{ }^{13} \mathrm{C} \mathrm{RMN} \mathrm{(50.5} \mathrm{MHz,} \mathrm{CDCl}_{3}\right) \delta 172.5,156.9,119.6,80.4,78.1,74.2$, 65.1, 57.5, 49.1, 38.2, 30.1, 29.4, 28.2, 27.0, 25.2, 20.3 ppm. Anal. Calcd. for $\mathrm{C}_{18} \mathrm{H}_{28} \mathrm{~N}_{2} \mathrm{O}_{5}$ : C, 61.34; H, 8.01; N, 7.95. Found: C, 61.37; H, 8.08, N, 7.97.

$\left(2 R^{*}, 3 R^{*}, 5 S^{*}\right)-5-\left(3^{\prime}\right.$-Acetoxypropyl)-2-ethyl-3-(4"'-terc-butoxycarbonylpropylamino)tetrahydro-furan, 15 and $\left(2 S^{*}, 3 S^{*}, 5 R^{*}\right)-2-(3$ '-acetoxypropyl)-5-ethyl-3-(4' 'tercbutoxycarbonylpropyl-amino)tetrahydrofuran (16). Colorless oil, 15:16 = 60:40

IR $\left(\mathrm{CHCl}_{3}\right) \vee 1715,1220 \mathrm{~cm}^{-1} .{ }^{1} \mathrm{H} \mathrm{RMN}\left(300 \mathrm{MHz}, \mathrm{CDCl}_{3}\right) \delta 0.85$ (m, 6H), 1.35-1.60 (m, 18H), 2.02 (s, 3H), 2.15 (m, 1H, 15), 2.25 (m, 1H, 16), 2.60 (m, 2H), 3.30 (m, 1H), 3.60-3.80 (m, 2H), 4.05 (m, 2H) ppm. ${ }^{13} \mathrm{C}$ RMN (50.5 $\left.\mathrm{MHz} \mathrm{CDCl}_{3}\right) \delta$ 171.2, 158.7, 82.6, 82.2, 79.1, 64.4, 56.7, 46.2, 36.2, 31.4, 28.2, 25.8, 23.6, 22.4, 20.9, 11.2, 10.6 ppm. Anal. Calcd. for $\mathrm{C}_{19} \mathrm{H}_{35} \mathrm{NO}_{5}$ : C, 63.84; H, 9.87; N, 3.92. Found: C, 63.87; H, 9.90, N, 3.94. 


\section{Acknowledgements}

Ministerio de Ciencia y Tecnología (Project BQU2000-0653) is gratefully thanked for financial support. One of us (M.C.M) thanks Ministerio de Educación y Cultura (Spain) for a pre-doctoral grant.

\section{References and Notes}

1. (a) Vogel, P.; Cossy, J.; Plumet, J.; Arjona, O. Tetrahedron 1999, 55, 13521. (b) Vogel, P. Current Org. Chem. 2000, 4, 455.

2. For the Pauson-Khand reaction see: Arjona, O.; Csákÿ, A. G.; Murcia, M. C.; Plumet, J. J. Org. Chem. 1999, 64, 7338

3. For ROM-CM see: (a) Arjona, O.; Csákÿ, A. G.; Murcia, M. C.; Plumet, J. J. Org. Chem. 1999, 64, 9739. (b) Arjona, O.; Csákÿ, A. G.; Murcia, M. C.; Plumet, J.; Mula, M. B. J. Organometal. Chem. 2001, 627, 105. (c) Arjona, O.; Csákÿ, A.G.; Plumet, J. Synthesis 2000, 857.

4. For a preliminary communication on the domino metathesis on endo allyl and propargyl ethers see: Arjona, O.; Csákÿ, A. G.; Murcia, M. C.; Plumet, J. Tetrahedron Lett. 2000, 41, 9777

5. (a) Schuster, M.; Blechert, S. Angew. Chem., Int. Ed. 1997, 36, 2036. (b) Grubbs,R. H.; Chang, S. Tetrahedron 1998, 54, 4413. (c) Fürstner, A. Angew. Chem., Int. Ed. 2000, 39, 3012. (d) Maier, M. E. Angew. Chem., Int. Ed. 2000, 39, 2073. (e) Undheim, K.; Efskind, J. Tetrahedron 2000, 56, 48. (f) Trnka, T. M.; Grubbs, R. H. Acc. Chem. Res. 2000, 34, 18 and therein cited references.

6. For the domino metathesis in norbornene systems see: Stragies, R.; Blechert, S. Synlett 1998, 169.

7. Arjona, O.; Fernández, R.; Mallo, A.; Pérez, S.; Plumet, J. J. Org. Chem. 1989, 54, 4158.

8. For the ocurrence of this skeleton among natural products see: (a) Dictionary of Natural Products on CD-ROM; Chapman and Hall/CRCnet Base, Version 8.1, August 1999. (b) Knapp, S. Chem. Rev. 1995, 95, 1859. (c) Leeuwenburgh, M. A..K Kulker, C.; Duynstee, H.K.; Overkleeft, H. S.; van der Marel, G. A.; van Boom, J. H. Tetrahedron 1999, 55, 8253.

9. Compound $\mathbf{7}$ was isolated instead of $\mathbf{6 a}$ (minor regioisomer). This can be explained by an in situ dimerization of the domino metathesis intermediate under these reaction conditions.

10. The reactivity of the imines derived from 1a has been scarcely considered in the literature. See: Arjona, O.; Mallo, A.; Manzano, C.; Plumet, J.; Galbis, J.; Jaime, C. J. Chem. Soc. Perkin Trans II 1988, 865. 
11. Compared to cyanide addition to aldehydes, few literature references describe the asymmetric synthesis of $\alpha$-amino acids with a quaternary $\alpha$ - center by this procedure. See: Cativiela, C.; Díaz-de-Villegas, M. D. Tetrahedron Asymm. 1998, 9, 3517.

12. For the first RCM process in cyclic enamides see: Kinderman, S. S.; Van Maarseveen, J.; Schoemaker, H. E.; Hiemstra, H.; Rutjes, F. P. J. T. Org. Lett. 2001, 3, 2045.

13. (a) Fu, G. C.; Nguyen, S. T.; Grubbs, R. H. J. Am. Chem. Soc. 1993, 115, 9856. (b) Wright, D. L.; Schulte, J. P.; Pages, M. A. Org. Lett. 2000, 2, 1847.

14. The domino metathesis of endo propargyl ethers derived from 7-oxanorbornene has also been reported to be highly regioselective (ref. 4). In this case, the regioselectivity stems from the formation of a vinylcarbene when the domino metathesis reaction commences by cyclometallation of the triple bond. 